\section{Leukæmia-inhibiting Properties and L-Asparaginase Activity of Sera from Certain South American Rodents}

GUINEA pig serum is known to exert a striking inhibitory effect on certain transplantable leukæmias of the mouse and rat ${ }^{1}$. Suppression may be seen, not only with long transplanted leukrmias, but also with recently derived spontaneous and radiation-induced leukæmias (preceding communication). Other sera have been tested, but none has shown unequivocal activity ${ }^{1,2}$. The only rodent other than the guinea pig, the serum of which has been examined and found to be negative, is the rat ${ }^{2}$. Up to the present time, however, no animal closely related to the guinea pig has been studied.

For this reason, we have obtained a number of South American rodents of the same sub-order, Hystricomorpha, in order to test the activity of their serum against transplanted leukæmias. In view of Broome's contention that this inhibition is mediated by the $\mathrm{L}$-asparaginase content of guinea pig serum ${ }^{3}$, we have also determined the activity of this enzyme in each serum sample.

A mouse leukæmia recently induced by $\mathrm{X}$-radiation in a (C57BL/6xA $H_{1}$ hybrid, $E A R A D 1$, was selected for these tests. This leukæmia has been found to be highly sensitive to suppression by guinea pig serum. Except in two instances where the serum of the species tested was toxic, $1 \mathrm{ml}$. of serum was injected intravenously at the time of subcutaneous inoculation of $1 \times 10^{6}$ leukæmia cells into isogenic hosts. The two toxic sera, porcupine and capybara, were injected subcutaneously in volumes of $1 \mathrm{ml}$. and $0.5 \mathrm{ml}$. respectively. Similar volumes of guinea pig serum injected by the subcutaneous route have been found to suppress the leukæmia used in the work recorded here. Under the conditions of these experiments, no adverse effect whatsoever was observed after the injection of any of these sera.

It can be seen from Table 1 that serum from all members of the super-family Cavioidea, with the exception of the capybara, showed both protection against the leukæmic graft and L-asparaginase activity. The only serum with $\mathrm{L}$-asparaginase activity, but no protective action in vivo, was the capybara specimen. However, from other experiments in which amounts of guinea pig serum with comparable $\mathrm{L}$-asparaginase activity were injected subcutaneously, protection by the capybara serum was not to be expected. This relatively low level of activity of the capybara serum may be related to the immaturity of our specimen. The levels of L-asparaginase in the sera from the paca and Patagonian hare approximated the values for individual guinea pigs. Agouti serum showed considerably greater activity than guinea pig serum. In guinea pigs, the highest value found was 169 units $\mathrm{L}$-asparaginase $/ \mathrm{ml}$. the individual values for agoutis were $370,480,550,583$ and 720 units $/ \mathrm{ml}$.
Serum specimens from Hystricomorpha other than the Cavioidea were entirely devoid of both leukæmia-inhibitory and L-asparaginase activities. The serum of another more distantly related rodent, the hamster, was also found to lack both properties.

The fact that serum from three distinct genera, other than the guinea pig, possessed both $\mathrm{L}$-asparaginase and the property of inhibiting an experimental leukæmia, strengthens Broome's conclusion that these two characteristics are causally related ${ }^{3}$. From further experiments with serial dilutions of serum, we have obtained evidence that the same quantitative relationship exists between leukæmia inhibition and L-asparaginase activity, irrespective of the source of the serum.

It is also of interest that serum L-asparaginase activity appears to be confined to one relatively small group of rodents the classification of which into a single superfamily, Cavioidea, has hitherto depended on anatomical similarities. This distinetive distribution of L-asparaginase in serum provides an additional example of the applicability of biochemical methods to the study of phylogenetic relationships.

We thank Dr. H. Heck, Catskill Game Farm, Now York; Mr. G. E. Welch, Louisiana Wild Life and Fisheries Commission; Mrs. J. Steiner, Mahopac, New York; Dr. R. Van Gelder, American Museum of Natural History, New York; Mr. J. A. Davies, New York Zoological Park, Bronx, New York; and Mr. F. Penman, Tarpon Zoo, Tarpon Springs, Florida, for help in obtaining specimens.

This work was supported in part by a National Institutes of Health general research grant.

L. J. OLD

E. A. Boyse

H. A. Campbeli

G. M. Daria

Division of Experimental Chemotherapy,

Sloan-Kettering Institute for Cancer Research,

Cornell Medical College, New York, and Department of Pathology,

New York University School of Medicine, New York.

${ }^{1}$ Kidd, J. G., J. Exp. Med., 98, 565 (1953).

${ }^{2}$ Herbut, P. A., and Kraemer, W. H., Amer. J. Path., 34, 767 (1958).

${ }^{3}$ Broome, J. D., Nature, 191, 1114 (1961).

4 Meister, A., in Methods in Enzymology, edit. by Colowick, S. P., and Kaplan, N. O., 2, 383 (Academic Press, New York, 1955).

\section{Isolation of a Murine Leukæmogenic Virus P-LLV}

THE induction of lymphocytic leukæmia and other morphologic forms of reticular neoplasms has been reported in various strains of mice by cell-free agents isolated from leukæmic tissues or from long-transplanted neoplasms of non-reticular origin ${ }^{1-7}$. Agents producing profound hæma-

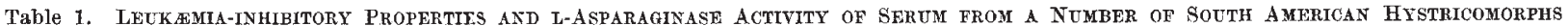

\begin{tabular}{|c|c|c|c|c|c|}
\hline \multirow[b]{2}{*}{ Super-family } & \multirow[b]{2}{*}{ Specimen * } & \multicolumn{3}{|c|}{ Leukæmia-inhibitory activity } & \multirow[b]{2}{*}{$\begin{array}{l}\text { L-Asparaginase act- } \\
\text { ivity } \dagger \text { of serum } \\
\text { (units } / \mathrm{ml} \text {.) }\end{array}$} \\
\hline & & $\begin{array}{l}\text { Treatment } \\
\text { with serum }\end{array}$ & $\begin{array}{c}\text { Survivors/mice } \\
\text { inoculated with } \\
\text { leukæmia } \ddagger\end{array}$ & $\begin{array}{l}\text { Average survival time } \\
\text { of mice dying with } \\
\text { leukæmia (days) }\end{array}$ & \\
\hline $\begin{array}{l}\text { Chinchilloidea } \\
\text { Hystricoidea } \\
\text { Octodontoidea } \\
\text { Cavioidea } \\
\text { Cavioidea } \\
\text { Cavioidea } \\
\text { Cavioidea } \\
\text { Cavioidea }\end{array}$ & 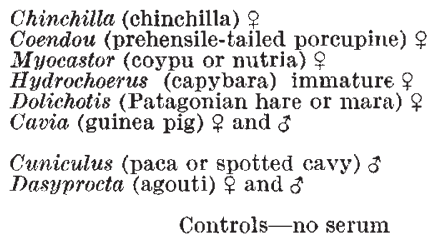 & $\begin{array}{l}1 \mathrm{ml} . \text { i.v. } \\
1 \text { ml.s.c. } \\
1 \text { ml.i.v. } \\
0 \cdot 5 \text { ml.s.c. } \\
1 \text { ml.i.v. } \\
1 \text { ml. i.v. } \\
1 \text { ml. i.v. } \\
1 \text { ml. i.v. }\end{array}$ & $\begin{array}{c}0 / 4 \\
0 / 4 \\
0 / 4 \\
0 / 4 \\
3 / 4 \\
4 / 4 \\
\text { (pooled serum) } \\
4 / 4 \\
4 / 4 \\
\text { (single o serum) } \\
0 / 18\end{array}$ & $\begin{array}{c}18 \\
20 \\
21 \\
20 \\
26 \\
\text { all survived } \\
\text { all survived } \\
\text { all survived } \\
20\end{array}$ & $\begin{array}{c}<1 \\
<1 \\
<1 \\
32 \\
113 \\
115 \\
\text { (range } 71-169 \S \text { ) } \\
64 \\
583 \\
\text { (range } 370-720 \S \text { ) }\end{array}$ \\
\hline
\end{tabular}

* A serum sample from one individual of each genus was examined, except in the case of the chinchilla (serum samples from 2 animals pooled), guinea pig (individual serum samples from 14 animals) and agouti (individual serum samples from 5 animals).

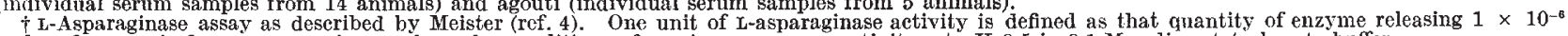
moles of ammonia from L-asparagine per $h$, under conditions of maximum enzyme activity, at $p \mathrm{H} 8.5$ in $0.1 \mathrm{M}$ solium tetraborate buffer.

Tests performed with $(C 57 B L X A) F_{1}$ o mouse leukæmia $E A R A D 1$ in isogenic hosts.

$\$$ Tests performed with $(C 57 B L X A) F_{1}$ i mouse 